\title{
Macrophage-Expressed Gene 1 Protein
}

National Cancer Institute

\section{Source}

National Cancer Institute. Macrophage-Expressed Gene 1 Protein. NCI Thesaurus. Code C148574.

Macrophage-expressed gene 1 protein $(716 \mathrm{aa}, \sim 79 \mathrm{kDa})$ is encoded by the human MPEG1 gene. This protein may be involved in host defense. 